\title{
RESEARCH ON APPROACHES FOR REGULATION OF THE "OFF-LABEL" USE OF MEDICINAL PRODUCTS IN THE EUROPEAN UNION
}

\author{
M. Drenska and I. Getov \\ Faculty of Pharmacy, Medical University - Sofia
}

\begin{abstract}
Despite the increasingly strict legislation on medicinal products, the „off-label use" or "use of medicinal product outside the approved summary of product characteristics $(S m P C)$ " is a weak point of today's drug regulation and raises many questions about the risk, ethics, and legality of this type of practice. In recent years, through guidance and legal changes in some countries were defined the conditions and responsibilities, but in the most European countries still lack rules for off-label prescribing. The purpose of this study was to identify and analyse different approaches to regulation, adopted by some member states as well as to summarize the efforts in demand of common harmonized approach to solve this problem within the European Union. In the study, we used the available regulatory information in different electronic resources associated with the off-label drug use in selected European countries without limited time range. The results show that decisions taken to regulate the issue have significant differences and specific approach, while none of them is enough satisfactory and comprehensive. In conclusion, it can be claimed that the existing regulatory rules in various countries require significant improvement and update.
\end{abstract}

Key words: off-label use, drug legislation, drug regulation, off-label regulation

Corresponding author: M. Drenska, MD, Faculty of Pharmacy, e-mail: maria.drenska@gmail.com

\section{INTRODUCTION}

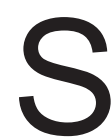
tudies show that about $40 \%$ of medicines in adults, to over $90 \%$ in children, are used „offlabel" i.e. outside the approved summary of product characteristics [8].

Most affected are children, mental, cancer patients and patients with rare diseases where simply there is no alternative treatment with available authorized medicinal products (drugs).

The European Medicines Agency defines the use of medicinal products outside their product characteris- tics as „situations where a medicinal product is intentionally used for a medical purpose, not in accordance with the authorised product information" [10].

Considering that the intentionally use of medicinal products without the necessary authorization would be interpreted by the Bulgarian, respectively European, legislation as a legal violation, this phenomenon becomes a weak point of today's drug regulation.

Despite the increasingly strict legislation in drug regulation, all European countries raise questions about the risk, ethics, and legality of this type of practice, 
which clearly indicates the need of establishment of rules to regulate off-label drug use.

\section{OBJECTIVE}

To study different approaches for regulating off-label use of medicinal products in the European Union.

\section{MATERIAL AND METHODS}

Legal documents, manuals, expert opinions, scientific publications and the available regulatory information, which is related to the off-label use in selected European countries (France, Italy, Spain, Germany, the United Kingdom, Bulgaria) and found using electronic resources such as PubMed, Google Scholar and Google, were studied and analyzed.

\section{RESULTS}

\section{France}

In 2012, France, in order to meet the needs of public health and to control the off-label use, introduced very original temporary regulatory framework: „Temporary recommendations for use“ („Temporary Recommendations for Use", RTUs) [4].

Between 2012 and 2014, RTUs underwent two changes, with purpose under economic reasons to circumvent the mandatory until then requirement the medicinal product allowed under this procedure not to have an authorised alternative [5].

This amendment raises a number of resentments by the European Federation of Pharmaceutical Industries and Associations (EFPIA), according to which such actions by health authorities encourage off-label drug use.

To date, according to these "temporary recommendations for use", 13 medicinal products are allowed for off-label use [13].

\section{Italy}

Law 648/1996 is the main legal instrument in Italy, which regulates the off-label use. According to it, certain medicinal products published in the so-called „list 648 ", could be used in the absence of a valid therapeutic alternative. The Italian Drug Agency (Agenzia Italiana del Farmaco, referred to as „AIFA) is obliged to maintain and periodically update this list [18].

Over the years additional legislation is introduced $(94 / 1998,296 / 2006)$, which further regulates the offlabel use $[12,15]$. Following the decision of the Italian authority for the protection of competition (Autorità Garante Della Concorrenza e del Mercato, called
„AGCM“) and in the interest of society, in 2014 Italian Government converted law 648/1996 (Legislative Decree 36/2014) into new law 79/2014, which allows and justifies off-label use even if there is an alternative treatment [7].

Here, as in France, the law provoked a number of reactions from the EFPIA, according to which the wide authority of the AIFA and inclusion in the "648 list" of cheaper alternatives helps maintain this type of practice.

\section{Spain}

Opposite to France and Italy, in Spain, there is no procedure by which a medicinal product can be allowed to be used off-label, but prescription outside the SmPC is regulated by Royal Decree 1015/2009 $[6,17]$.

"The difference from other regulations is that is given freedom....." or "The difference from other regulations is that physicians are free to consider whether off label drug to be applied....". What is particularly is that is given freedom to the physicians responsible for the treatment to consider whether an off-label drug to be applied in a particular situation, without special permission from the drug agency. For this purpose, following conditions need to be met:

- no other medicinal product licensed in Spain, which is already authorised to be used in the specific indication according to its SmPC, is available;

- off-label use must be authorised by the health authority of the region where the healthcare centre is located;

- the doctor responsible for the treatment must justify in writing the reasons why the patient should use a specific medicinal product under off-label conditions;

- the patient must consent in writing to the off-label prescription, after having been informed about the benefits and risks of the treatment.

\section{Germany}

The use of a medicinal product outside the SmPC in German drug law (Arzneimittelgesetz, AMG 2005) is not considered. The law only allowed exceptions in some cases where authorization is not necessary (Section 21, Art. 1, 2 and 6) [14].

The off-label use is determined and regulated by the Federal Joint Committee (G-BA), which was established in 2004 according to the German Social Code (Art. 92) and it involved doctors, dentists, hospitals, health insurance companies and is the highest authority in the field of health [11]. G-BA has the power to 
update policies and take routine decisions regarding health care in Germany, including to regulate and determine the off-label prescription (according to Annex VI of the German directive on drugs) [3]. According to established procedure, the G-BA considers requests for off-label use (only for drugs already authorized in Germany) and comes with an updated „positive list", which is published for reference of physicians, health insurance companies and other interested parties [16].

\section{United Kingdom}

Off-label drug use in the United Kingdom is not covered by basic health law (The Human Medicines Regulations 2012), but is regulated by the General Medical Council (GMC), which is an independent regulator, whose aim is to protect the health and safety of the public by ensuring proper standards in the physicians practice.

Physicians themselves are obliged to comply with the standards of good practice, set out in guidelines published by the Council, including guidelines for prescribing drugs not authorized for use in the UK, as well as those that are used outside the terms of the SmPC.

For the first time, guidance that provides recommendations in this regard was established in 2008 and since then has changed several times. In the final version of the guidance from 2013, medicinal products can be prescribed outside the terms of the SmPC when [9]:
- there is no suitably licensed medicine that will meet the patient's need;

- a suitably licensed medicine is not available;

- the prescribing forms are part of a properly approved research project.

Additionally, the physician must meet the following conditions:

- to be satisfied that there is sufficient evidence or experience of using the medicine to demonstrate its safety and efficacy;

- to take responsibility for prescribing the medicine and for overseeing the patient's care, monitoring, and any follow up treatment;

- to make a clear, accurate and legible record of the reasons and medicines prescribed.

\section{Bulgaria}

In Bulgaria, in the law on Medicinal Products in $\mathrm{Hu}-$ man Medicine (Art. 8) there are considered situations, in which exceptionally permit is not required, but those situations do not include the off-label drug use [1].

The use of medicinal product outside of SmPC is not covered by any other law or regulation and it practically became forbidden when the medical audit executive agency penalized leading ophthalmologists in 2014 [2].

Table 1. Review of national provisions on the off-label use in selected European countries

\begin{tabular}{|c|c|c|c|c|c|c|}
\hline & $\begin{array}{c}\text { Natlonal law or regulation on } \\
\text { "off label use" }\end{array}$ & Relevant Instltutions & Klnd of regulation & In fores ince & $\begin{array}{c}\text { Presence of procedure } \\
\text { for } \\
\text { approval of speclific off- } \\
\text { lebeluses }\end{array}$ & $\begin{array}{l}\text { Presence of Informed Consent } \\
\text { In case of off-tabel use (expllicity } \\
\text { statutorllyregulated) }\end{array}$ \\
\hline FRANCE & Regulaton No $2012-743$ & $\begin{array}{l}\text { National Agency for the Safet/ of } \\
\text { Med oine and Health Products (ANSM) }\end{array}$ & $\begin{array}{c}\text { Temporary } \\
\text { recommendationsfor use } \\
\text { (RTU) }\end{array}$ & 2012 & Yes & No \\
\hline ITALY & $\begin{array}{l}\text { Law648/1996, Law 94/98 } \\
\text { (Leqged Bela), Law } \\
\text { 296/2005, Law 36/2014 }\end{array}$ & Italan Medione Agency (AFA) & Condsons for off-labeluse & 1996 & Yes & Yes \\
\hline SPAIN & Poyal Decree 1015/2009 & $\begin{array}{l}\text { Spanish Agency for Medicines and Helth } \\
\text { Products(AEMPS) }\end{array}$ & Condtoons for off-bbel use & 2009 & No & Yes \\
\hline GERMANY & Socal Code Book V & $\begin{array}{l}\text { The Federal Joint Comm ttae (G-BA) } \\
\text { under Federal Instute for Drugs and } \\
\text { Medical Devices ( BfarM) }\end{array}$ & $\begin{array}{l}\text { Recomendatons on off. } \\
\text { labd use }\end{array}$ & 2004 & ves & No \\
\hline UNITED KINGDOM & $\begin{array}{c}\text { Good practce inprescribing } \\
\text { and managing medches and } \\
\text { defloes }\end{array}$ & UK General Medical Counci & Gidelne for physldans & 2008 & No & No \\
\hline BULGARIA & No & Bulgatan Drug Agency & Na & N/A & No & No \\
\hline
\end{tabular}


Table 2. Review of the process for approving off-label use in France, Italy and Germany

\begin{tabular}{|c|c|c|c|c|}
\hline & $\begin{array}{c}\text { Off label approw al can be issued } \\
\text { when }\end{array}$ & Off label approval can be issued by & $\begin{array}{l}\text { Off label uee can be } \\
\text { approved by }\end{array}$ & Duration of approw al \\
\hline FRANCE & authorized altemative exists & $\begin{array}{l}\text { - Mristry of health } \\
\text { - FrenchS ocial Security ministry } \\
\text { - The institution incharge of Social Security } \\
\text { Insurame (UNICAM) } \\
\text { - Health Technology Assessment agency (HAS) } \\
\text { - The National Cancer Institute (INCa) } \\
\text { - Reference certers for rare diseases } \\
\text { - Approved patient associations }\end{array}$ & $\begin{array}{l}\text { French National Agency for } \\
\text { Medicines and Health } \\
\text { Products S afety } \\
\text { (ANSM) }\end{array}$ & 3 years (renewable) \\
\hline ITALY & anthorized altemative exists & $\begin{array}{l}\text { - Physicians specialised in the treatment of the } \\
\text { proposed disease } \\
\text { - Universities } \\
\text { - Research centres }\end{array}$ & $\begin{array}{l}\text { ItalianMedicines Agency } \\
\text { (AIFA) }\end{array}$ & No lmitation \\
\hline GERMANY & authorized altenntive doesrit tesis ts & $\begin{array}{l}\text { - G-BA inpartials } \\
\text { - The Certral Federal Association of Health } \\
\text { Insurame F unds } \\
\text { - The National Association ofS tatutory Health } \\
\text { Insurame Plysicians (KBV) } \\
\text { - The National Association ofS tatutory Health } \\
\text { Insurame Dertists (KZBV) } \\
\text { - The Geman HospitalF ed eration(DKG) } \\
\text { - Patient repres entatives. }\end{array}$ & $\begin{array}{l}\text { Federal Joint Committe } \\
\text { (G-BA) }\end{array}$ & No Imitation \\
\hline
\end{tabular}

\section{DISCUSSION}

Off-label use of drugs is possible under certain conditions and procedures in examined member states, except for Bulgaria. It is a widespread practice that is not limited to any specific clinical situation or to a separate state. Our review of national legislation shows that in all examined member states, except Bulgaria, approaches have been taken to regulate and control the off-label use.

The measures taken are showing significantly different and specific approach. Some are within the health legislation, another are under national security legislation, while others represent guidelines of national associations (Tab. 1).

The analysis shows that none of the decisions taken for regulation is sufficiently satisfactory and comprehensive. There are objections from doctors, patients and pharmaceutical companies, as against drugs entering into „permitted lists“ for economic reasons and against the very specific approval procedures (Tab. 2 ), mainly because they could not meet the needs of patients in emergency and/or life-threatening situation, where the physician must act and take decisions very fast.

The problem concerning "off-label use" does not seem to have been found yet found its principle and universal solution, despite the huge efforts being made by regulatory authorities in different countries.
Basically, what remains unsolved, although the proposed solutions, is that in almost all countries physicians and patients still feel uncertainty in their actions when they use drugs off-label. This problem is partially resolved in the approaches of the UK and Spain, where the decision and responsibility for offlabel use, mainly lies in the hands of the physicians.

\section{CONCLUSION}

Modern medical practice and development of pharmaceutical science require all member states to introduce a regulatory framework regarding off-label drug use. Existing regulatory rules in various countries require significant improvement and continuous updating. To ensure access to high quality and safe medicines for the population of the European Union it is necessary to seek a harmonized solution and approach, using the experience of applied different strategies in different member states in order to guarantee cross-border mobility of patients and health professionals.

\section{REFERENCES}

1. Закон за лекарствените продукти в хуманната медицина. Available at: http://www.badibg.org/badilaws/Lawhuman/Z_ lec_pr_pdf. Last access: 2016/10/27.

2. Ценкова, И., Я., Люцканов. Off-label: Забранените лекарства, 2014. Available at: http://www.temanews.com/index. php?p=tema\&iid=836\&aid=18858. Last access: $2016 / 10 / 27$. 
3. Administration of pharmaceuticals for unauthorized indications (off-label use). Federal Joint Committee. Available at: http://www.english.g-ba.de/special-topics/pharmaceuticals/ off-label/. Last access: 2016/10/27.

4. Degrassat-Theas, A., F., Bocquet, M., Sinegre, et al. The "Temporary Recommendations for Use“: A dual-purpose regulatory framework for off-label drug use in France. Health Policy, 119, 2015, 1399-405.

5. Emmerich, J., N., Dumarcet, A., Lorence. France's new framework for regulating off-label drug use. N Engl J Med., 367, 2012, 1279-81.

6. Faus, J., X., Moliner. Spain - Law \& Practice - Life Sciences 2017 - Chambers and Partners, 2017. Available at: http:// practiceguides.chambersandpartners.com/practice-guides/ life-sciences-2017/spain/37-access-to-unauthorised-products Last access: 2017/01/09.

7. Galimberti, G., M. Mostardini, M. Turrini, E. Marchesoni. The Life Sciences Law Review. Ch.18: Italy. R. Kingham, 4. London, Law Business Research Ltd, 2016, 298p. Available at: https://www.twobirds.com/ /media/pdfs/news/articles/2016/ italy.pdf?la=en Last access: 2017/01/09

8. Gazarian, M., M., Kelly, J.R., McPhee, et al. Off-label use of medicines: consensus recommendations for evaluating appropriateness. Med J Aust., 185, 2006, 544-8.

9. Good practice in prescribing and managing medicines and devices (2013). Available at: http://www.gmc-uk. org/guidance/ethical_guidance/14316.asp. Last access: 2016/10/27.

10. Guideline on good pharmacovigilance practices (GVP), Annex I - Definitions (Rev 3) Available at: http://www.ema. europa.eu/docs/en_GB/document_library/Scientific_guideline/2013/05/WC500143294.pdf. Last access: 2016/10/27.
11. Legal mandate, procedures - Federal Joint Committee. Available at: http://www.english.g-ba.de/legalmandate/. Last access: 2016/10/27.

12. Lenk, C., G. Duttge. Ethical and legal framework and regulation for off-label use: European perspective. Ther Clin Risk Manag., 10, 2014, 537-46.

13. Liste des spécialités faisant actuellement l'objet d'une RTU. Available at: http://ansm.sante.fr/Activites/Recommandations-Temporaires-d-Utilisation-RTU/Liste-des-specialitesfaisant-actuellement-I-objet-d-une-RTU/(offset)/1 Last access: 2017/01/09.

14. Medicinal Products Act (The Drug Law). Available at: http:// www.gesetze-im-internet.de/englisch_amg/index.html . Last access: 2016/10/27.

15. Minfrini, F. Italian competition authority targets big pharma, triggers expansion of off-label prescription- Italy Legal Focus, 2014. Available at: http://www.legal500.com/developments/27204 Last acces: 2016/10/27

16. Obermann, S. Off-Label Use of Medicines - General Aspects, Challenges and Strategies - Master-Thesis, 2013. Available at: http://dgra.de/deutsch/studiengang/masterthesis/2013-Sonja-Obermann-Off-Label-Use-of-Medicines$\%$ E2\%80\%93-General-Aspects,-Challenges-and-S Last acces: $2016 / 10 / 27$

17. Peire, M.A. Legal responsibility prescribing off-label drugs: is spain different? Archives of Disease in Childhood, 101. e1., 2016. Available at: http://adc.bmj.com/content/101/1/e1.57. Last access: 2017/11/01

18. Prada, M., C., Bertozzi, B., Proietti, D., Urbinati. The Italian 648/96 List: Approvals, Rejections and Methods In Aifa\&\#x2019; s Evaluation Process Between January 2013 and May 2015, Value in Health, 18,7, 2015, A680. 